Volume 2 Nomor. 2, Oktober 2017

P -ISSN : 2541-1179, E-ISSN : 2581-1711

OJS :http://journal.uin-alauddin.ac.id/index.php/instek/index

\title{
DETEKSI CAIRAN INFUS MELALUI SMS BERBASIS MIKROKONTROLLER ARDUINO UNO
}

\author{
Risnawaty Alyah \\ Dosen Teknik Elektro \\ Fakultas Teknik Universitas Sawerigading Makassar \\ risna.alyah@yahoo.co.id
}

Infus disebut juga dengan Intravenous Fluid Drops (IVFD), diartikan sebagai jalur masuk cairan melalui pembuluh vena. namun pada kenyataannya cairan infus meiliki jenis yang macam - macam, sehingga tidak serta merta dikatan bahwa infus adalah makanan pengganti bagi orang sakit.Alat infus yang khususnya sering digunakan pada pasien ruang rawat inap masih menggunakan sistem pemantauan secara manual dan bisa saja perawat atau keluarga pasien yang mengawasi pasien tidak memperhatikan tetesan cairan infus karna sedang tidur, terutama apabila pada jam-jam istirahat pada malam hari alat infus ini terkadang tidak terpantau jika suatu waktu alat infus ini berhenti menetes. Penelitian ini mengajukan suatu gagasan untuk medeteksi tetesan infus dengan sistem informasi melalui SMS yang akan dikirim ke perawat yang berada di ruangan perawat maupun di ruangan lainnya, perawat dapat mengetahui lebih cepat kondisi cairan infus setiap pasien di ruangan perawatan. Metodologi penelitian ini melakukan study literatur, dan merancang alat yang dapat bekerja secara automatis dengan menggunakan modul GSM. Serta sistem kontrol menggunakan Arduino Uno. Hasil yang diperoleh setelah dilakukan pengujian waktu pengiriman SMS ke perawat dengan kesalahan 3\% dari waktu pengiriman sms dari modul gsm yang diprogram pada SIM800L ke handpone operator selama 8 detik. Sehingga alat ini layak untuk digunakan pada ruang, ICU.dan ruangan Perawatan lainnya.

Kata kunci : Mikrokontroler arduino uno, sensor photodiode, dan SMS.

\section{PENDAHULUAN}

Infus disebut juga dengan Intravenous Fluid Drops (IVFD), diartikan sebagai jalur masuk cairan melalui pembuluh vena. Meski pada kenyataannya cairan infus meiliki jenis yang macam - macam, sehingga tidak serta merta dikatan bahwa infus adalah makanan pengganti bagi orang sakit.

Pemberian cairan melalui infuse adalah pemberian cairan yang diberikan pada pasien yang mengalami pengeluran cairan atau nutrisi yang berat. Tindakan ini membutuhkan kesteril-an mengingat langsung berhubungan dengan pembuluh darah. Pemberian cairan melalui infus dengan memasukkan kedalam vena 
Volume 2 Nomor. 2, Oktober 2017

P -ISSN : 2541-1179, E-ISSN : 2581-1711

OJS :http://journal.uin-alauddin.ac.id/index.php/instek/index

INFORIATIKASANS DAN TEROLOOG

Email : instek@uin-alauddin.ac.id

(pembuluh darah pasien) diantaranya vena lengan (vena sefalika basal ikadan median akubiti), pada tungkai (vena safena) atau vena yang ada dikepala, seperti vena temporalis frontalis (khusus untuk anak-anak).

Pemasangan infus merupakan sebuah teknik yang digunakan untuk memungsi vena secara transcutan dengan menggunakan stilet tajam yang kaku dilakukan dengan teknik steril seperti angeocateter atau dengan jarum yang disambungkan dengan spuit (Eni K, 2006). Pemasangan infus adalah salah satu cara atau bagian dari pengobatan untuk memasukkan obat atau vitamin ke dalam tubuh pasien (Darmawan, 2008).Sedangkan infus adalah memasukkan cairan dalam jumlah tertentu melalui vena penderita secara terus menerus dalam jangka waktu tertentu (Azwar, 2009). Sementara itu menurut Lukman (2007), pemasangan infus intravena adalah memasukkan jarum atau kanula ke dalam vena (pembuluh balik) untuk dilewati cairan infus/pengobatan, dengan tujuan agar sejumlah cairan atau obat dapat masuk ke dalam tubuh melalui vena dalam jangka waktu tertentu. Tindakan ini sering merupakan tindakan life saving seperti pada kehilangan cairan yang banyak, dehidrasi dan syok, karena itu keberhasilan terapi dan cara pemberian yang aman diperlukan pengetahuan dasar tentang keseimbangan cairan dan elektrolit serta asam basa. Jadi dapat disimpulkan bahwa pemasangan infus adalah sebuah teknik memasukkan jarum atau kanula kedalam vena untuk memasukkan cairan infus kedalam tubuh.

pada saat ini pemasangan alat infus khususnya yang sering digunakan pada pasien ruang rawat inap masih menggunakan sistem pemantauan secara manual dan bisa saja perawat atau keluarga pasien yang mengawasi pasien tidak memperhatikan tetesan cairan infus karna sedang tidur, terutama apabila pada jam-jam istirahat pada malam hari alat infus ini terkadang tidak terpantau jika suatu waktu alat infus ini berhenti menetes. 
Volume 2 Nomor. 2, Oktober 2017

P-ISSN : 2541-1179, E-ISSN : 2581-1711

OJS :http://journal.uin-alauddin.ac.id/index.php/instek/index

Email : instek@uin-alauddin.ac.id

\section{METODE PENELITIAN}

Metodologi yang digunakan dalam pengerjaan penelitian ini terbagi menjadi beberapa tahap seperti yang ditunjukkan pada gambar berikut flow chart proses penelitian pembuatan alat deteksi cairan infus :

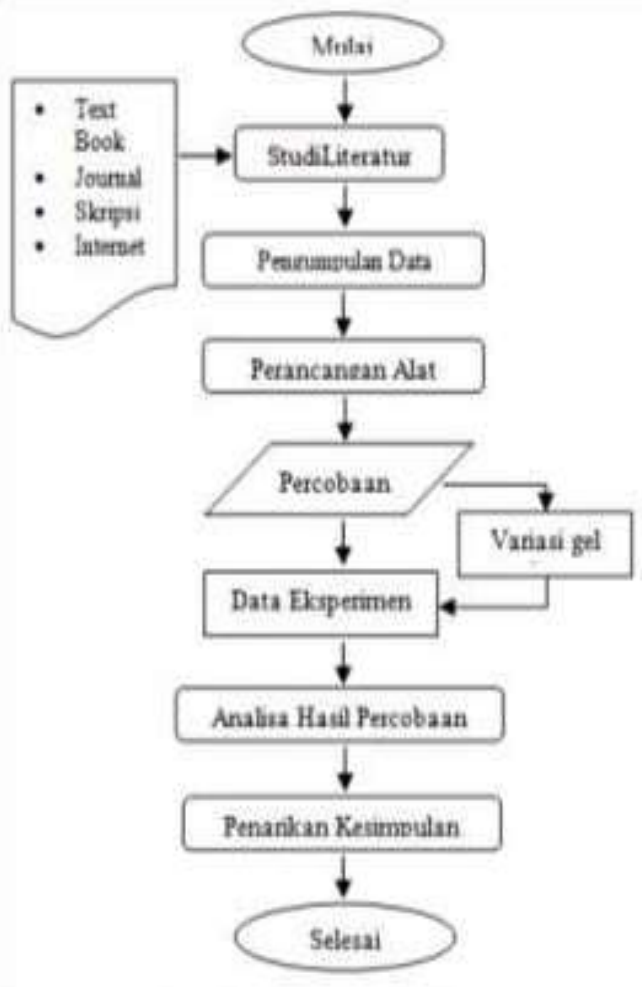

Gambar 1. Flow Chart Penelitian

\section{A.Study Literatur}

Pada tahap ini merupakan tahapan awal dari pengerjaan tugas akhir. Pada tahap ini dilakukan pengumpulan bahan pustaka dan literatur-literatur yang diperlukan dalam mendukung pengerjaan penelitian ini. Pada pengerjaan penelitian ini literatur pendukung yang digunakan diperoleh dari buku, jurnal, laporan tugas akhir, serta dari internet. Literatur yang diambil dalam tugas akhir ini berkaitan dengan ilmu kesehatan, teknologi elekronika, sistem kontrol dan alat infus. 
Volume 2 Nomor. 2, Oktober 2017

P-ISSN : 2541-1179, E-ISSN : 2581-1711

OJS :http://journal.uin-alauddin.ac.id/index.php/instek/index

Email : instek@uin-alauddin.ac.id

\section{B.Pengumpulan Data}

Pada tahap ini dilakukan pengumpulan data-data yang diperlukan untuk merancang serta menganalisa performa sistem kerja alat infus. Dilakukan percobaan pada alat yang telah di buat dengan menggunakan kontrol.Percobaan dilakukan dengan memvariasikan waktu pemakaian dan usia pengguna kemudian dikaukan penganatan pada monitor LCD, untuk mengetahui kesesuaian fungsi alat dengan program yang telah di masukkan pada mikrokontroller

\section{C.Kerangka Konsep}

Berikut gambar blok diagram dari Rancang bangun sistem deteksi tetesan cairan infus dengan SMS

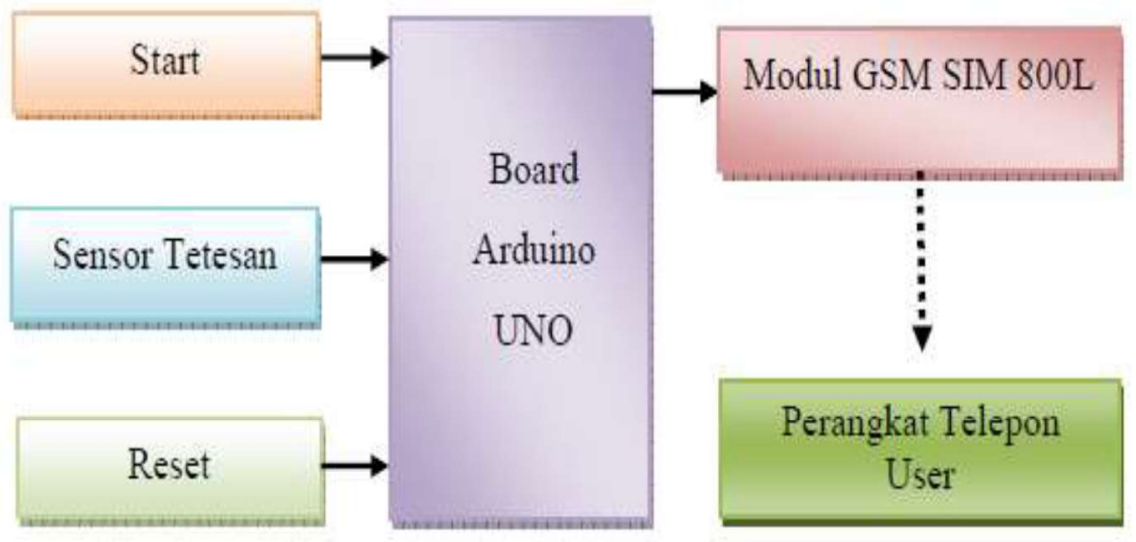

Gambar 2. Blok diagram

\section{D.Perancangan Alat}

Pada tahap ini dilakukan proses perancangan alat yang terdiri dari dua bagian yaitu mekanik dan elektrikal atau sistem kontrol, dari perancangan alat ini dibuat desian alat dan bahan dan peralatan yang digunakan seperti ; sensor, motor DC, mikroklontroller, relai , kapasitor transformator, LCD, buzzer dan lain lainnya, setelah itu dirancang alat kontrolnya dengan menggunakan mikrokontroller Arduino Uno, 
Volume 2 Nomor. 2, Oktober 2017

P -ISSN : 2541-1179, E-ISSN : 2581-1711

OJS :http://journal.uin-alauddin.ac.id/index.php/instek/index

Email : instek@uin-alauddin.ac.id

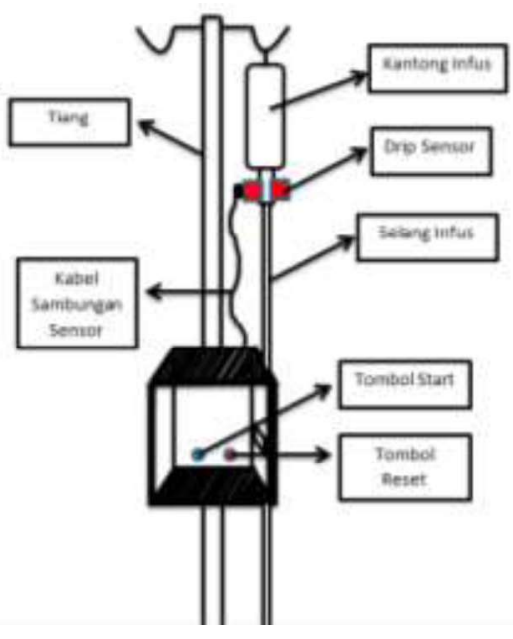

Gambar 3.Desain Perancangan Alat

\section{HASIL DAN PEMBAHASAN}

\section{A. Hasil Desain}

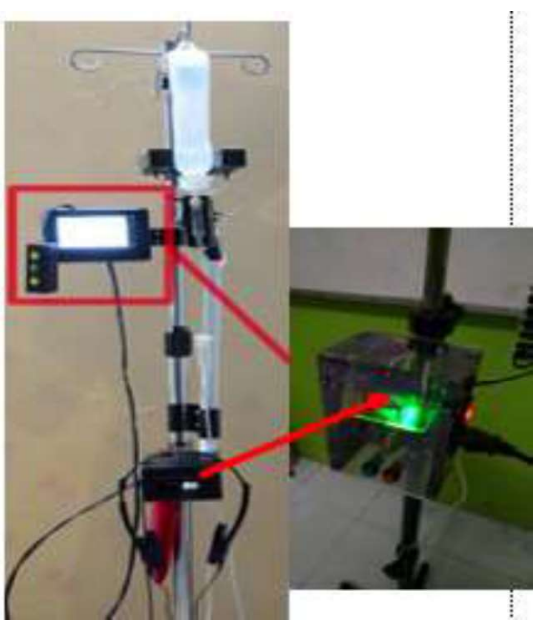

Gambar 4. Hasil Desain Alat Secara Keseluruhan 
Volume 2 Nomor. 2, Oktober 2017

P -ISSN : 2541-1179, E-ISSN : 2581-1711

OJS :http://journal.uin-alauddin.ac.id/index.php/instek/index

INFORMATKASAMIS DAN TERNOLOGL

Email : instek@uin-alauddin.ac.id

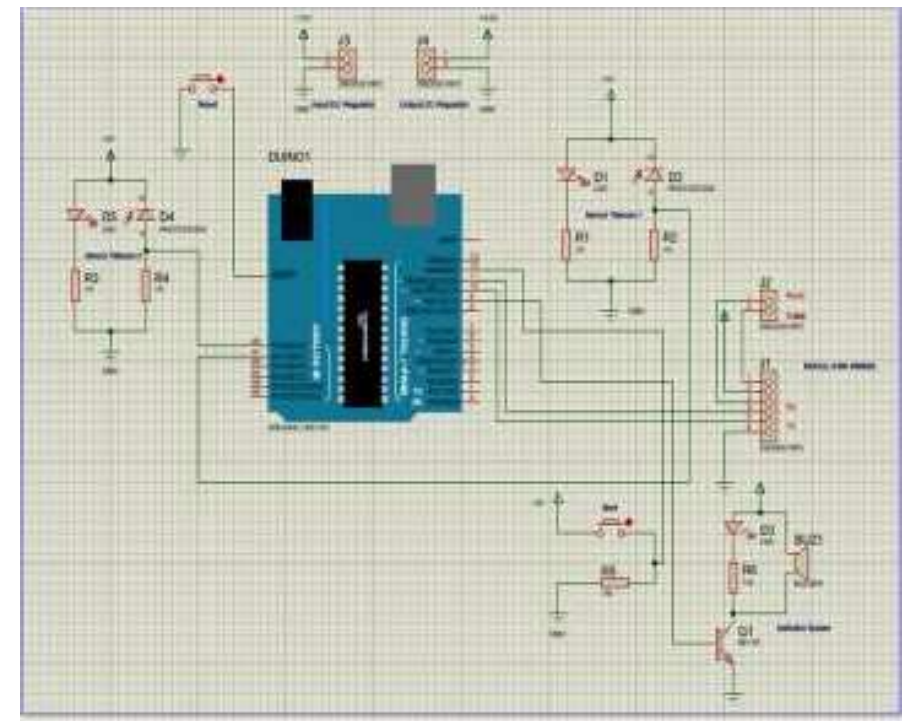

Gambar 5. Rangkaian Elektronik keseluruhan sistem

\section{B. Hasil Percobaan}

Pada tahap ini dilakukan analisa terahadap data-data yang telah diperoleh. Data-data yang diperoleh akan dianalisa dengan melakukan perhitungan dengan menggunakan variabel rata rata (mean), rata rata simpangan,(error),standar deviasi, dan ketidakpastian. dan pengujian fungsi alat kepada pasien

Setelah membuat modul maka perlu di adakan pengujian dan pengukuran, untuk itu diadakan pendataan melalui proses pengukuran dan pengujian. Tujuan pengukuran dan pengujian adalah untuk mengetahui efektifitas dan keakuratan modul yang di buat. Pengukuran waktu mengirim SMS ke user di lakukan beberapa kali dalam percobaan,

Tabel 1. Hasil pengujian waktu pengiriman SMS dalam detik

\begin{tabular}{|c|c|c|c|}
\hline Percobaan & $X n$ & $\mathbf{X n - X _ { \text { rata } }}$ & $\begin{array}{c}(\mathrm{Xn}- \\
\text { Xrata })^{2}\end{array}$ \\
\hline 1 & 8,5 & 0,24 & 0,0576 \\
\hline 2 & 8,1 & $-0,16$ & 0,0256 \\
\hline 3 & 8,1 & $-0,16$ & 0,0256 \\
\hline 4 & 8,3 & 0,04 & 0,0016 \\
\hline \multirow[t]{3}{*}{5} & 8,3 & 0,04 & 0,0016 \\
\hline & 41,3 & & \\
\hline & Xrata $=8,26$ & & $\Sigma=0,112$ \\
\hline
\end{tabular}




\section{Analisa Perhitungan}

1. Rata Rata (mean)

$$
\begin{gathered}
\text { Rata Rata }(\bar{X})=\frac{\sum X_{n}}{n} \\
(\bar{X})=\frac{41,3}{5} \\
(\bar{X})=8,26
\end{gathered}
$$

7. Koreksi (k)

$$
\begin{gathered}
k=T_{\text {setting }}-T_{\text {rata rata }} \\
k=8-8,26 \\
k=-0,26
\end{gathered}
$$

8. Kesalahan (Error)

$$
\begin{gathered}
\text { Error }=\frac{8-8,26}{8} \times 100 \% \\
\text { Error }=-3 \%
\end{gathered}
$$

9. Simpangan rata-rata (SR)

$$
\begin{gathered}
S R=\frac{\sum X_{n}-\bar{X}}{n} \\
S R=\frac{41,3-8,26}{41,3} \\
S R=0,8
\end{gathered}
$$

10.Standart deviasi (SD)

$$
\begin{gathered}
S D=\frac{\sqrt{(X 1-\bar{X})^{2}+\cdots(X n-\bar{X})^{2}}}{n-1} \\
S D=\frac{\sqrt{0,112}}{4} \\
S D=\frac{0,335}{4} \\
S D=0,084
\end{gathered}
$$


Volume 2 Nomor. 2, Oktober 2017

P -ISSN : 2541-1179, E-ISSN : 2581-1711

OJS :http://journal.uin-alauddin.ac.id/index.php/instek/index

Email : instek@uin-alauddin.ac.id

11. Ketidakpastian (Ua)

$$
\begin{gathered}
U a=\frac{S D}{\sqrt{n}} \\
U a=\frac{0,084}{\sqrt{5}} \\
U a=0,037
\end{gathered}
$$

Pengukuran fungsi waktu alat untuk mengirim SMS ke user dengan standar waktu 8 detik yang telah ditetapkan dalam program dan percobaan mengambil sampel 5 kali. Dengan tingkat kesak

\section{Skematik Sensor Tetesan / Cairan Infus}

Rangkaian sensor tetesan sebagai sensor yang berfungsi mendeteksi apakah ada tetesan cairan infus, prinsipnya ialah mengirim data output sensor untuk kemudian diolah oleh arduino rangkaian ini tersusun atas komponen LED IR dan Photodiode dengan resistor. Output dari sensor tersebut diperoleh dari sambungan kaki anoda photodiode.

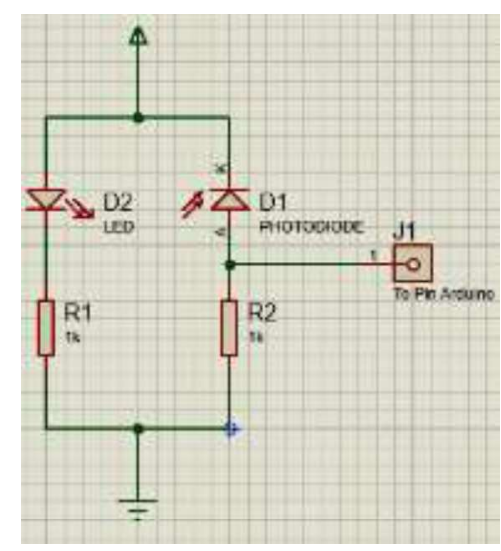

Gambar 6. Diagram sensor

\section{List Program}

Void setup()\{

\}

Void loop()\{

int sensorValue = analogRead $(A O)$;

// print out the value you read:

if (sensorValue $<=350$ )

\{

delay(5000);

sms1();

exit(0);

\} 
else \{

Rangkaian Modul GSM SIM800L

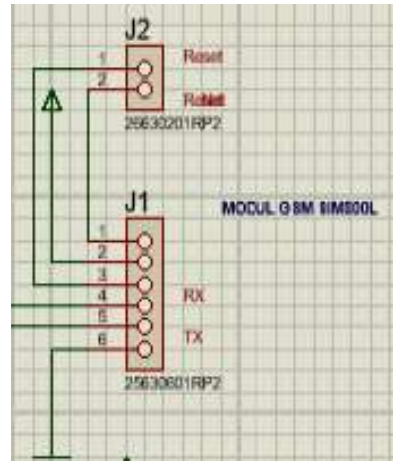

Gambar 7. Diagram GSM SIM800L Modul

\section{List Program Modul GSM SIM800L}

void sms1() \{

Sim800l.begin(); // initializate the library. text="Infus Habis.......!!!! Mohon Isi Kembali!!!"; //text for the message.

number="081241690230"; //change to a valid number.

error=Sim800I.sendSms(number,text);

\}

\section{IV.KESIMPULAN}

1. Alat deteksi cairan infus yang dibuat bertujuan untuk memberikan informasi yang real time dan cepat melalui pengiriman SMS ke operator atau perawat dengan memasukkan nomor telpon

2. Kesalahan atau keterlambatan waktu dari setting time yang diprogram alat ini pada pengiriman SMS keperawat sekitar 3\% sehingga alat ini masih layak digunakan.

3. Pengiriman SMS dapat secara bersamaan kepada beberapa perawat sesui jumlah nomor telpon yang dimasukkan dalam program.

4. Keterbatasan alat ini karena setiap nomor yang akan dituju dinput dulu dalam program. 
Volume 2 Nomor. 2, Oktober 2017

P -ISSN : 2541-1179, E-ISSN : 2581-1711

OJS :http://journal.uin-alauddin.ac.id/index.php/instek/index

Email : instek@uin-alauddin.ac.id

\section{DAFTAR PUSTAKA}

Azwar, S. 2009. Sikap Manusia Teori dan Pengukurannya. Jogjakarta : Pustaka Pelajar Offset.

Aryawi, 2009 Cairan Infus. http://aryawitl.blogspot.co.id/2009/02/cairan infus.html

Belajarduino.2016ModulArduino,http://www.belajarduino.com/2016/05/sim8001gsmgprs-module-to-arduino.html

Dougherty, L., dkk. (2010). Standards for infusion therapy: The RCN IV therapy forum.

Darmawan. 2008. Amino dan Protein. http://www.darmaqua.blogspot.com

Hasan, Lukman, Dkk. 1998. Instrumentasi Elektronika Dan Teknik Pengukuran. Jakarta: Balai Pustaka

Kusyati, Eni. 2006. keterampilan dan prosedur laboraturium keperawatan dasar. Jakarta:EGC

Lukman. (2007). Intravena Terapi. http://www.sehatgrup.com. Di akses pada tanggal 12 Agustus 2017

Potter, P.A, Perry, 2005, A.G.Buku Ajar Fundamental Keperawatan : Konsep, Proses, dan Praktik.Edisi 4.Volume 2.Alih Bahasa : Renata Komalasari,dkk.Jakarta:EGC.

Potter, P.A, Perry, 2005, A.G.Buku Ajar Fundamental Keperawatan : Konsep, Proses, Dan Praktik.Edisi 4.Volume 1.Alih Bahasa : Yasmin Asih, dkk. Jakarta : EGC.

Sabarudin, Gufron 2008 ,'Dual Infus Pump Berbasis Mikrokontroller”, Karya Tulis Ilmiah. POLTEKES Surabaya, 2008

Tutorbagus, 2017, cara mengirim sms, , menggunakan modul https://tutorbagus10.blogspot.co.id/2017/01/cara-mengirim-smsmenggunakan-modul.html 